\title{
Social Media in an Emergency: Use of Social Media in Rescuing Abducted School Girls in Nigeria
}

\author{
Muhammad Maigari Abdullahi \\ Uthman Abdullahi Abdul-Qadir
}

\begin{abstract}
This article examines how different social media platforms were used in the context of mass mobilization for social support. The objectives of the the paper is to examine how social activists used social media to generate reactions and support for the abducted schoolgirls in Nigeria across the globe. The paper adopted the theory of Philanthropy to explain how different organizations, groups, and philanthropists came to the aid of the victims and assisted the Nigerian government. Methodologically, this task was approached through the collection of secondary data. The data was analyzed based on the research questions raised in the paper. Social media platforms and other tactics of the social movement have been decisive in attracting the attention of the world towards the abducted girls. The study found that the use of social media platforms is an effective medium of drawing for support for people in an emergency. The study further revealed that both the abducted schools and the Nigerian government received foreign and domestic assistance to help address the insecurity challenge. The girls freed by the Boko Haram insurgents were offered scholarships in Nigeria and outside as a measure for reformation and rehabilitation. Therefore, the paper concludes that internet-enabled communication has reduced time and space in human interaction which facilitates and accelerates social interactions. It has also become an important medium for easy mobilization for social support from any part of the world.
\end{abstract}

Keywords: social media, emergency, Boko Haram insurgency, abducted school girls, Nigeria

\section{Introduction}

Maintaining and managing internal security has been a prerogative of the nation-states. Political, ethnic and religious conflicts and boundary disputes are perennial occurrences in developing countries in Africa, Latin America, and Asia. The resultant effects of these internal strifes are the number of people displaced by the unrests, violence and chaos. These conflicts have produced unprecedented catastrophe and humanitarian emergencies in the affected areas and in the neighbouring countries. These neighbouring countries often struggle to handle displaced persons who flee for their life because they lacked financial strength to cater the needs of the refugees. Africa in particular, has witnessed an increase in election-related conflicts from the 1990s to 2015 (Bowd \& Chikwanha, 2010). However, many of the conflicts surrounding elections are complex and often have much to do with the manipulation of constitutions by incumbent presidents. There is also a destructive culture of failing to honour and accept electoral outcomes by contesting parties which is a major threat to peace (Bowd \& Chikwanha, 2010, p13).
At the global perspective, the aftermath of September $11^{\text {th, }} 2001$ terrorist attacks in the USA has ushered new dimension in the security architecture of the world. The war on terrorism championed by the USA and their allies have taken the centre stage of the world politics and diplomatic discourse, which overshadowed other important issues. The war on terrorism in Afghanistan, Iraq and some Gulf countries has forced the insurgents or fighters to shift or move their operational base to African countries, where there are weak border security and failed State like Somalia and collapsed nation like the Central African Republic and Libya. Nigeria has been immersed with the security challenges arising from Islamist insurgents in the Northeast of the country apart from the perennial communal, political and religious violence that has become the trademark of the country since independence from Britain in 1960.

The Boko Haram insurgency in Nigeria has reached its climax in 2009 after the killing of its leader Muhammad Yusuf by the Nigerian Police Force. Since 2009, the militants have been launching suicidal attacks on government establishments, schools, security installations and innocent civilians. The Boko Haram fighters burnt and ransacked more than 100 villages in Adamawa, Borno

This work is licensed under the Creative Commons (C) Muhammad Maigari Abdullahi \& Uthman Abdullahi Abdul-Qadi

Muhammad Maigari Abdullahi: Assistant Research Fellow at the Department of Sociology, AL-Qalam University Katsina Nigeria. Email: kariyoma2@yahoo.com/https://orcid.org/0000-0002-7928-029X

Uthman Abdullahi Abdul-Qadi: A Senior Lecturer, at the Department of Sociology, Faculty of Social Sciences, Usmanu Danfodiyo University Sokoto-Nigeria.

Email: Uthman50@yahoo.com/https://orcid.org/0000-0002-7471-4861 
and Yobe States in Nigeria from 2009-2019. The Boko Haram-related insurgency in these states (Adamawa, Borno, and Yobe) has caused population displacement, disruption in livelihoods, and acute food insecurity (CadreHarmonise, 2016, p1). Similarly, findings in 2017 showed the magnitude of the violence. In Nigeria, for example, a middle-income country, the Boko Haram-related armed conflict is concentrated in the north-east of the country as well as spilling into neighbouring countries. By the end of 2016, 1.8 million people had been displaced and 14 million were in need of humanitarian assistance in the six most affected states (Development Initiatives, 2017, p23). Before then, at least 1.3 million children have been uprooted by Boko Haram violence across four countries in the Lake Chad region (UNICEF 2016, p1). Among the displaced person, children and women were the worst hit by the heinous acts of the insurgents in the Northeastern Nigeria, which is the main thrust of this research. The objectives were to examine how the global citizens swiftly reacted to the abduction of the school girls. To assess how global citizens' uproar over the abduction of the schoolgirls has generated reactions across the world to free the schoolgirls from captivity.

However, what was uncommon in the response of people to insecurity challenges is the application of modern communication technologies to draw the attention of the world to the plight of the victims of violence; which has been new and unique, especially in Africa, which is technologically backward. During the first half of this decade, between the year 2010 and 2015, many important social movements were formed. Unlike the social movements of old, these new social movements were not restricted to the countries where they started. Through social media and new communication technologies, they rapidly spread beyond borders, attracting millions of sympathizers from far away countries (Ugorji, 2017, p7). The Arab Spring that started in Tunisia in 2010 and spread to many countries in North Africa and the Middle East; the Occupy Wall Street that began in 2011 in Zuccotti Park, New York City and rapidly expanded to many other countries; and the Black Lives Matter movement that was created in 2013 and quickly gained momentum and membership from many Blacks in different U.S. States and other countries around the world, are just a few examples. In addition to these movements, and with a different goal and way of organizing, the world witnessed a torrential social movement that emerged from Nigeria in 2014 with a ripple effect in many other countries. Bring Back Our Girls made international headlines and millions of people from many countries, faiths, ethnicities, and races were mobilized in support of their common cause - a cause rooted in the restoration of the dignity and safety of abducted schoolgirls in Borno State Nigeria (2017, p7).

To examine how social media, help to raised concern over the abducted schoolgirls in Chibok to receive global attention, the paper asked some pertinent questions: Why the abducted schoolgirls received global sympathy? How social media contributed to the spread of campaign for the release of schoolgirls from captivity? To answer these questions, the researcher dwelled on secondary data and analysed the activities of the social activists and campaigners who championed the course of the Chibok girls within and outside Nigeria. Therefore, the rationale behind the above discourse is how internet and social media, due to their ability to multiply information at high speed and at little cost, are increasingly used for propaganda, information warfare, and influence operations, all of which can tangibly change both the perception and behaviour of the target audience. It is a highly dynamic, user-driven, constantly changing environment where it is easy to get a message to 'go viral', and also difficult to track the initial source of information, verify its authenticity, and separate fact from fiction (Lange-Ionatamishvili \& Svetoka, 2015).

\section{Interrogating the Literature}

\section{Social Media: A Tool for Mobilizing Support}

Social media platforms have a pivotal role in some instances to strengthen good governance while in some, weakened domestic security in some countries. Social issues bothering the citizens in both developed and developing nations are discussed or shared among the citizens. India for example, social media platforms contributed to coordinating large-scale protests across the country. The slogan was 'India against Corruption', a movement led by Anna Hazare in 2011. While these protests were largely peaceful, they tested the local security infrastructure in terms of sheer numbers (Pandalai, 2016).

Social media platforms enable activists and social movements to self mediate' and to distribute movement goals or frames more easily. Social movements and activists have always done. This, but social media are said to greatly increase the capacity to transmit text and visual discourses. It has been observed that social media platforms have the potentials to provide (new) opportunities for citizens' participation in governance. It also gives underprivileged groups in society power to bypass state and market controls and the mainstream media to construct alternative collective identities (Cammaerts, 2015). Similarly, in Chile, social media platforms were by social movement activists to educate, recruit and mobilized citizens to participate in protests (Valenzuela, 2012).

In Nigeria, the abduction of High School girls in April 2014 in Chibok, Borno State make the headlines in comparison to others as the conflict is easy to comprehend, it provides a unique story and has to have good timing (Adu-Atwere, 2015). The uniqueness of the story is the abduction itself, how the militia went about it, and the number of girls that were kidnapped, their identity and how the girls are promoted and used as leverage by Boko Haram (2015). In explaining how the attention of the world was drawn to rescue the abducted girls, social media and related new technologies have shifted away from government control over media information and towards a global market in which information cuts through and across geopolitical boundaries. Also, striking about today's 
media globalization is that it is largely driven by corporate interests: the producers and distributors of contemporary global media encompass about twenty multinational corporations, from Time Warner to Rupert Murdoch's News International (Elliott, 2009). Therefore, the social media campaign initiated by some social activists was intended to compel authorities to take an action or resist a policy is commonplace with the use of modern telecommunication platforms which enable campaigners to mobilize support from wide spectrum of population within a short time and at low cost. This is in contrast with traditional medium of communications like radio, television, newspaper, fax and fixed telephone which whose possession were considered elitist in most developing countries of Africa and cannot mobilize large number of people within a short time like internet-enabled social media outlets.

\section{Social Media and the Bring Back Our Girls Campaign: Chibok School Girls}

The preceding section highlighted link or interconnectedness between media and mass mobilization for collective action in society. Social crusaders employ diverse social media strategies on different platforms to press home their demands. It has been observed that without the media buzz and outcry, it would take a long time for the rest of the world to know the situation of the victims and activities of the Boko Haram insurgency in Northeastern Nigeria. However, radio was used and still in use to spread propaganda and mobilize people for common action because till date is less costly to purchase and easy to operate even among the uneducated in developing countries. This is one of the traditional means of dissemination of information is still relevant and explored for mass mobilization. On the contrary, its major disadvantage is, the listeners are passive, cannot contribute, comment and share the content of the news unlike the social media, which the users are at liberty to create, share and comment on any issue. To some, it is the user who generates the content of the message.

\section{The Insurgency: A Historical Sketch of Boko Haram}

Since 2009, acts of domestic terrorism perpetrated by the Jama'atu Ahlissunnah Lidda'awati Wal Jihad (People Committed to the Propagation of the Prophet's Teachings and Jihad"), also known as Boko Haram, have eclipsed Nigeria's long-standing security threats such as piracy, militancy, kidnappings, and armed robbery (Onuoha, 2013). The Nigerian Islamist militant group attracted worldwide attention beginning from July 2009, when it staged a violent anti-government uprising that resulted in the death of over 800 people, mostly its members. The group has since then ramped up violent attacks on diverse government and civilian targets, including a suicide bombing attack on the United Nations building, Abuja, on 26 August 2011. Over 3,500 people have been killed in violence blamed on the group, while tens of thousands more internally displaced by the insurgency and associated military crackdown (2013).

\section{The Global Response to the Abduction of School Girls}

There were massive reinforcements of different security personnel, strategies, apparatuses and expertise since the abduction of schoolgirls in 2014. Both domestic and international reactions have shown the commitments of government, organizations and groups to end the scourge of the insurgency and provide relief for the victims. After the girls were kidnapped, their parents and members of the public took to the streets of Abuja, Nigeria calling on the government to step up its efforts to rescue the girls. The domestic and international media attention pushed the government to take concerted effort on how to rescue the victims. The laxity of the government to react promptly has added to the perception that neither the government nor the military was able to handle the security situation properly and efficiently (Barna, 2014). This belief was based on the continuation of violence perpetrated by Boko Haram. The activities have become more deadly, and increasingly indiscriminate of their targets. In 2014 alone, there were more than 1,000 deaths attributed to Boko Haram, including the killing of 59 schoolboys in February 2014 in Yobe State.

In this regard, the social media campaign by the social activists across the world raised voices on the abduction of the schoolgirls in Chibok caught the attention of the world, notably on Twitter. Following the international protests, mounting social media campaigns and pressure, Boko Haram released a video that showed more than 100 of the missing girls. Given the proficient public relations abilities of the self-aware organization, it can be surmised that the video released which showed Boko Haram's leader, Abubakar Shekau was linked to the response of the international community (Donnelly, et al., 2014). Also, soon after the abduction, the United States and the United Kingdom sent specialist teams to bolster the Nigerian authorities in their search efforts. France hosted former President Goodluck Jonathan at a regional summit, while other countries including Canada, Australia, China, and Israel have also pledged support for the Nigerian government (2014). Although the Chibok case was outrageous, Boko Haram has carried out a number of abductions over the past few years that have not been covered by the media to such an extent. This may be down to a number of factors, including poor information networks and the remote location of some attacks, as well as media fatigue on reporting constant attacks (2014).

The assertions of Donnelly and Barna presented snapshots of the violence perpetrated by the Islamist insurgents and how it attracted the attention of global security, political and humanitarian circles. However, the works have not stated what facilitated the ventilation of the plights of the victims to the knowledge of the global community. This is because internet-based social networks in the $21^{\text {st }}$ century are used as tools to mobilize public 
attention to compel the government to address national security challenges. New technologies and in particular Social Media constitute an asset of great importance both for protest movements and for revolutions. Rebels and revolutionary groups turn to such tools to better organize and spur masses to action, to arrange protest or struggle activities and manage their tactical and operational aspects. Since Social Media is gaining a great deal of clout in determining the conclusion of protests and revolutions, their employment is likely to increase remarkably in the immediate future (Montagnese, 2012, p21).

\section{Social Media Campaign for the Abducted School Girls: \#BringBackOurGirls}

During the aftermath of the abduction of schoolgirls in Nigeria, social activists condemned the nonchalant attitude of the Nigerian government in handling the internal security of the country. Most of the citizens decried the carelessness of the security operatives, which allowed the insurgents to unleashed terror on soft targets: women and children. Dissatisfied with the response and effort of government and security agents to rescue or free the schoolgirls and other women in captivity, the campaigners decided to explore social media as a means to reach a large audience that can force the government to take decisive measures to rescue the kidnapped girls and other women from the Boko Haram insurgents. At the peak of the campaign, they used Twitter and Facebook page. The choice of Twitter was because it prominent personalities as its users across the world, who are influential in global politics, security and governance. Also, it is among the platforms which contributes in bringing government, international corporations, activists and philanthropists together to discuss, chat and comment on pertinent national and world issues. Similarly, the Twitter hashtags allow users to annotate tweets with metadata specifying the topic or intended audience of a communication.

For instance, the \#BringBackOurGirls movement played a key role in creating worldwide awareness about the plight of the abducted Chibok Secondary School female students. The campaign got its life, vitality, and vibrancy from the hashtag (Odeyemi \& Mosunmola, 2014). This is because the mass abduction of the Chibok girls shook Nigerians and spurred a social movement where citizens took to the streets of Abuja in protest and demanded the return of the girls. The movement quickly infiltrated online spaces and splashed throughout social media where celebrities like First Lady Michelle Obama and talk show host Ellen DeGeneres held up signs with the Twitter hashtag \#BringBackOurGirls (Smith, 2015). While social media has been studied and its contributions as a political platform and other public sphere during the Arab Springs and the Egyptian revolutions, the \#BringBackOurGirls social movement offers a variety of complexities surrounding gender, technology, religion, and political efficacy that continue s (four year later) to drive protest on and offline throughout Nigeria and other parts of the world. The hope and anger that ignite social movements (Castells,
2013) live on in the case of \#BringBackOurGirls, as evident in the tweets from users across the world that use the hashtag to express sorrow, sympathy, calls to action, questions, and point out other acts of terror or related cases of injustice against girls (2015).

Furthermore, the movement quickly gained momentum on social media, and \#BringBackOurGirls recorded the most tweeted hashtag of the time. Millions of Nigerians both in Nigeria and in the diaspora, as well as millions of social justice activists and ordinary people from many countries around the world, went to the streets with banners and posters that read Bring Back Our Girls. Celebrities, world leaders, foreign governments including President Barack Obama and the First Lady Michelle Obama made videos for the Bring Back Our Girls campaign and spoke passionately for the safe release and return of the kidnapped Chibok schoolgirls (2017). Apart from Nigerians, people from other countries also supported the mass movement campaign for the release of the abducted school girls. In the United Kingdom, University and the College Union added their voice in the call for the release of the Chibok girls. The UCU United Kingdom condemned the abduction of the Nigerian schoolgirls as well as other women and young girls abducted. As an education trade union, we value the right for women and girls to be educated, to live in societies free from fear and violence. The impact of not having access to education is huge and continues throughout life, not only in terms of access to decent jobs with a narrow or no pay gap with men but we know that educated women are less likely to die in childbirth, less likely to have children at an early age, and less likely to marry at an early age. Educated women have a greater awareness of their rights and greater confidence and freedom to make decisions that affect their lives and the lives of any children that they may choose to have (University and College Union, 2015).

This clearly showed the potency of social media in generating a response to social issues positively or otherwise among the target audience to achieve the aim of the movement. A study in India found that the convergence of various forms of media television, social, and online networks as instruments of information and generators of user content have multidimensional implications for law and order as well as security (Pandalai, 2016). This shows that social media is a double-edged sword: it is capable of igniting social unrest on one hand and restore public order in other. Additionally, the social media campaign for the release of the abducted schoolgirls in Chibok has also attracted the attention of Nobel Prize Winner Malala Yusuf. At the heart of the campaign in 2015, the Nobel Laureate stated that today and every day, we call on the Nigerian authorities and the international community to do more to bring you home. We will not rest until you have been reunited with your families. Like you, I was a target of militants who did not want girls to go to school. Gunmen shot me and two of my friends on a school bus. All three of us survived and are back in school. Now we speak out on behalf of all girls about the right to get a proper education. Our campaign will continue until you and all girls and boys around the world are able to access a free, safe and quality 
secondary education. Last July, I spent my $17^{\text {th }}$ birthday in Nigeria with some of your parents and five of your classmates who escaped the kidnapping. Your parents are grief-stricken. They love you, and they miss you (2015).

In the same vein, other global celebrities who could not visit Nigeria to take part in the protest for the release of the schoolgirls have utilized social media platforms (SMPs) to participate in the movement or campaign. This was evident where SMPs such as Facebook and Twitter were flooded with celebrities and world leaders holding up posters with the hashtag. Twitter was bursting with photos of protesters all around the world bearing banners with the hashtag. Suddenly, the world paid attention and even vowed to support Nigeria in its efforts at retrieving the abducted girls. The USA pledged to send a team, including military personnel, intelligence and hostage negotiators to help. Britain sent advisers and a Royal Air Force (RAF) surveillance aircraft to aid in the search. Analytics firm, Topsy, reports that within the first month of the kidnapping, the hashtag \#bringbackourgirls had been mentioned more than one million times all around the world. The world was definitely poised to think about the plight of the kidnapped girls. Protests were held around the globe to show solidarity to the cause. Even influential people such as the former United States of America's first lady, Michelle Obama, and Nobel Laureate Malala joined the bandwagon and posted pictures of themselves with posters bearing the hashtag. The world was suddenly urging the Nigerian government to act; to 'bring back our girls.' One may, however, speculate on the exact expectation of the \#bringbackourgirls campaign (Omoera \& Heri-Ryanga, 2016).

Therefore, it can be deduced from the above discourse that the people from all parts of the world expressed their sympathy and support of the schoolgirls. Other developed nations pledged to assist Nigeria with cuttingedge surveillance equipment and military gadgets to locate the girls and fight the insurgents simultaneously. The assistance has helped the Nigerian military to decimate the stronghold of the insurgents in Sambisa forest and rescued many captives from the Boko Haram.

\section{Impact of the Social Media Campaign}

Immediately after the victory of the opposition candidate at the 2015 General Elections in Nigeria, President Muhammadu Buhari moved the military command centre, which coordinates the fight against Boko Haram terrorists to Maiduguri, the Borno State capital. Similarly, the President further overhaul and the entire security architecture of the country with the appointment of new service chiefs: Chief of Defense Staff, Chief of Army Staff, Chief of Naval Staff and Chief of Air Staff as well as the Inspector General of Police. Recognizing the importance of the social media, the Nigerian Army Director of Public Relations was directed to create a Facebook account that would updates the citizens bit by bit unfolding events and on the spot information from the war front or any related latest development.
As stated above, the Bring Back Our Girls campaign has attracted the attention of international, humanitarian agencies, security and political actors to assist or broker a deal that would release the kidnapped girls and women in hands of terrorists. Red Cross International is one of the international organization, which facilitated the release of 106 girls in 2017. The Head of Delegation of ICRC, in Abuja, Eloi Fillion, stated that its role was the implementation of deals between the federal government and the insurgents. There were also individuals who initiated programmes to assist the victims of the insurgency. Good Samaritans provided clothes and food items for the victims of the insurgents while others established a school for the orphans and conflict-displaced children in Northeastern Nigeria. Notable among them is a legal practitioner based in Maiduguri, who established a school for children, who lost their parents in the conflict. In the school, the orphans receive free education, clothing and feeding. The gesture of Barrister Zanna Mustapha was brought to the public knowledge by the campaigners for the release of the abducted girls through sharing of the pictures of graduation event that took place in the school. This caught the attention of an international humanitarian agency United Nations High Commission for Refugees UNHCR. A founder of a school for orphaned children in Nigeria won a top United Nations award. The UNHCR's Nansen Refugee Award honours people who dedicate their lives to helping victims of war. Zannah Mustapha has helped children, whose parents were killed by the armed group Boko Haram. He also helped secure the deal to release schoolgirls held by the armed group (Soi, 2017).

Similarly, a Nigerian activist, Rebecca Dali has won the prestigious Sergio Vieira de Mello Foundation award for her work in re-integrating women and orphans abducted by Boko Haram militants into their home communities. The award was presented at a ceremony Monday commemorating World Humanitarian Day (August 19) at the UNO headquarters in Geneva. It is given every two years in memory of Sergio Vieira de Mello, who was killed in a terrorist attack on August 19, 2003, in Baghdad, Iraq, along with 21 others. The prize aims to draw world attention to the courageous, often unnoticed, humanitarian work of an individual, group or organization in areas of conflict (VOA News, 2017).

It could be deduced that social media has played a central role in compelling the Nigerian government to take drastic and decisive security measures, dialogue with the insurgents for the release of abducted school girls. The combined efforts of the social activists, Non-Governmental Organizations and International humanitarian institutions in both social media and traditional media has forced the Nigerian government to broker a deal with the insurgents mediated by the Red Cross and individuals. The negations succeeded and some of the kidnapped girls were freed. On May 2014, 57 of the schoolgirls escaped, May 2016: A missing schoolgirl found, October 2016: 21 girls were released to the Government of Nigeria, January 2017: two girls were rescued by the Nigerian Army (between Nov. 2016 -January 2017), May 2017: 82 girls were released to 
the Government of Nigeria. December 2017: one girl was rescued by the Nigerian Army. This indicates that social media-based campaign helped in the spread of the plights of the abducted girls, which traditional media platforms cannot. It also established that the due to the huge number of users and followers, it is an issue of concern for any democratically elected government, where there is a great public outcry, therefore the Nigerian government and humanitarian agencies are put on their toes to rescue the girls and end the Boko Haram insurgency.

\section{Theoretical Framework: The Theory of Philanthropy}

Humans as social beings usually unite to assist or solve a social problem that confronted them. Solutions to issues in the area of poverty, the environment, and lack of access to health care, education, water, and security were increasing to be found on a global level. The paper adopted a theory of philanthropy. This is because the theory treats external systems as context, which a foundation needs to understand sufficiently to identify opportunities and levers for impact. Also, the theory examines how the foundation's internal core reality (history, assets, priorities, procedures) provides opportunities and levers for impact (Patton, Foote, \& Radner, 2015). The internal-external connections constitute a road map for adding value in the world. The theory explained how social medial platforms generated reactions from different groups and foundations to render assistance for the abducted school girls. Foundations in this study comprise of different agencies, groups and organizations, which provided supports. International cooperation was considered indispensable in solving these issues (DGIS, 2009). The transition from 'public support for development cooperation' to 'global citizenship' therefore entails the abandonment of the North-South dichotomy, introducing reciprocity in the form of awareness of mutual dependency and allowing individual citizens to take centre stage.

It could be deduced from the conclusion of DGIS that it is a common practice now in the world for citizens from various countries to unite in order to proffer solutions to the problems of citizens of other countries that they have not met before or had no any form of contact; even before the invention of internet-based social networks. There are several United Nations agencies involved in several humanitarian services since the establishment of the UNO in 1945. However, the arrival of social media platforms has opened a new avenue for citizens' engagement and discussion. Individuals or group interaction, which sometimes they initiate an idea for social movement and mobilize resources to achieve their common goal or address a pressing problem.

\section{Methodology}

The paper utilized data from secondary sources. Both qualitative and quantitative data were derived from secondary sources and analyzed. The paper aim to examine how social media campaigns generated global outcry and motivated assistance from different parts of the world. Bryman (2008) observed that this type of analysis presents the possibility to access good quality data, which is probably conducted by more experienced researchers or organisations that have established mechanisms to ensure the quality of the data and have the necessary resources.

Similarly, the social platform used by most of the social activists was Twitter, which enable the activists and campaigners to generated hashtag \#bringbackourgirls. The paper consulted comments and posts between May 2014, when the campaign for the release of the abducted girls started to 2016, when this article was written. The years witnessed intense activities and actions of the social campaigners both on internet and physical. The researchers analyzed comments that are relevant to the topic of discourse at that time. Therefore, comments which were considered meaningless and not useful were not considered for analysis in this paper.

Tabular presentation of the total received/collected comments/posts under the \#tag

\begin{tabular}{|c|l|l|c|c|c|}
\hline $\begin{array}{c}\text { Joined } \\
\text { Twitter }\end{array}$ & Tweets & $\begin{array}{c}\text { Fol- } \\
\text { low- } \\
\text { ing }\end{array}$ & $\begin{array}{c}\text { Fol- } \\
\text { low- } \\
\text { ers }\end{array}$ & Likes & $\begin{array}{c}\text { Photos } \\
\& \text { Vid- } \\
\text { eos }\end{array}$ \\
\hline May 2014 & $23.9 \mathrm{k}$ & 98 & $34.7 \mathrm{~K}$ & 4,788 & 1,440 \\
\hline Facebook & & & & $223 \mathrm{k}$ & \\
\hline
\end{tabular}

\section{Word-Cloud}

A sample of postings and comments generated are presented. The researchers for the purpose of space, decided to sample two Facebook and Tweeter posts and their comments as required by the reviewer.

\section{FACEBOOK}

Congratulations to one of the \#ChibokGirls that escaped \#BokoHaram. 112 remain in captivity. \#BringBackOurGirls

\section{Debra Kurre Congratulations!}

Vera Lustig: A mighty achievement. Well done, and all the best for the future. We must free the remaining girls and ensure their wellbeing.

Please Find our Daughters and Bring Them Home April 7, 2019.

Esther Heusser-Faessler: has been thinking of this heartbreaking tragedy every single day, since it has happened. She is praying for justice and can't understand why no force of the world was able to free them so far.

Wore Wali: The memory of the Chibok Girls almost always drag me back into the mud of confusion. In spite this, am penning down " The Deed of the Past" in memory of them. Collectively, we shall \#Bring Back Our Girls

Emily Lindner: I thought they were found last year and returned?

Jodi Hill: So sad. I can't imagine going through this x Christa McCarthy: Has it really been 5 years!

Edeh Jude Okechukwu: During voting everybody was 
quiet.

Claudia Elaine Alexander: So sad, they are not forgotten, just don't know how to help.

Naomi Olive: I still think of these girls, many of them would have grown so much. Just heartbreaking

Aadesegunn Wwendyy: It is absolutely disgraceful! Shame on the government!

Philomena Idegbesor Ekhator: Shame to our governments. This is sad.

Ron Poirier: It can't play the Race Card because it his Blacks vs Blacks Michelle Obama Queen of Racist. These girls are not Rich enough for Obama to help but Smollett Bum Boy no PROBLEM.

\section{Twitter}

219 abducted schoolgirls are still missing. Let's take actual action and try to make a difference. See wiki for details. \#BringBackOurGirls

\#Lagos? Sat at 11 am on the Marina. \#Abuja? 4pm Unity Fountain. We won't stop until our girls are back and alive! Join us! \#BringBackOurGirls

Ghana, \# dreamday42 \# NoHungryChildGh, \# Africa! God \# BringBackOurGirls \# ChibokGirls !

April $14^{\text {th }}, 276$ school girls were kidnapped by Boko Haram terrorists. We will not stop advocating for them, until all are rescued.

Founder, Girl Child Africa ...working towards a world, where women and girls can live and thrive without inhibitions. \#BringBackOurGirls \#ChurchToo \#Goalkeeper

\section{Discussion of Major Findings}

The findings revealed that internet-based social media platforms have the capacity to disseminate information across the globe instantaneously to millions of connected users and followers. It further showed that most of the people in other parts of the world came to know the abduction of the schools in Chibok through social media especially through Twitter and Facebook. In the same vein, they used the same medium to express their support, concern, and solidarity for those in captivity, demand unconditional release and assist the victims to restart a new life. This is in line with the theory of philanthropy, different organizations, groups and individuals came to the aid of the victims. Furthermore, it correlates with the submission of Hadji (2016), which stated that with their popular appeal and multimodal affordances, social media, new media enabled by internet revolution and infrastructure, such as YouTube, Twitter and Facebook, as well as emails and blogs, have provided a platform for granting visibility to and facilitating the organization of activism.

It could be deduced from the findings that cutting-edge innovations in Information Communication Technology (ICT) have significantly reduced the distance between space and time. This helped social activists from different countries to come together and fought a common cause. It has removed traditional barriers to fast communication and dissemination of information, erected by the colonial masters and despotic leaders in developing countries where security information is kept under utmost secrecy and out of public consumption. This was visible in the unification of the world into a global village has enabled the people irrespective of their country of origin to participate or engage in a campaign or protest for something took place millions of kilometres away. Therefore, in the technologically driven-era, people are not only interested in their domestic issues or help only people within confines of their territorial boundaries. They are sympathetic and concern about took place thousands of miles away. This correlates with the finding of Zeitzoff (2017) which found that social media play dual roles, in conflict and contentious politics. He observed that politicians, insurgents and protestors all have used it as a tool for communication.

It could be inferred from the findings that social media campaigners have attracted foreign donors who helped ten of the released girls to complete their High School in the United States of America in 2017. Similarly, some of the freed girls were enrolled for free at American University in Yola, Adamawa State Nigeria. Additionally, local and international organizations have developed some initiatives to assist the released girls to start a new life and reintegrate them with their family members to eliminate the stigma that some girls, who have children with the Boko Haram fighters may encounter in the society. Therefore, it can be inferred from the discussion that social media platforms can use to resonates response from a target. This correlates with the conclusion of Nissen (2015), which maintained that internet, cyberspace, and social media can be used to collect intelligence or even to target people and organisations. Such tactics may be employed in isolation, but they are much more likely to be an integral part of a larger strategy.

\section{Conclusion}

The pace at which information move and the responses from people across the world portends that social media has the potency to bring the world together to address a pressing humanitarian exigency at any part of the world. People now express a strong bond of friendship and support during any social mishap, security challenge and natural disaster, which occurred in any country. The innovations in the information and communication technologies have enabled people across the world to engage in virtual discussions on the social media platforms, people share ideas, knowledge and proffer solutions to problems for issues and events from places that are separated by millions of miles away from their countries of origin. This points at the direction which the world is moving in the $21^{\text {st }}$ century; which yielded benefits for the victims of the Boko Haram insurgency, where some were released and the Nigerian government received military assistance from different countries to address its internal security challenges. It has enabled the arrival of international assistance in the area of military equipment and humanitarian services, which led to the release of some girls in captivity and relief materials 
to the victims.

In addition, without social media campaigns and the responses from the people around the world, the Nigerian government would have neglected the issue of the schoolgirls like other people abducted by the Boko Haram fighters since the beginning of the insurgency in 2009. Social media has now become a veritable tool capable of strengthening the security of a nation. It can be used to draw support for the government in moments of security challenges like the Bring Back Our Girls campaign has made some countries to help Nigeria in the search of the abducted girls and fighting the Islamist insurgents. The US government lifted arm procurement ban on Nigeria, sold more than fifty anti-landmine armour carriers. Early 2018, the Kingdom of Saudi Arabia assisted Nigeria with about ten million US Dollar. However, it is also capable of undermining or weakening the security architecture of a state as it happened during the Arab Spring. The world is fast moving towards an era where internet basedcommunication enable people to interact and discuss without restrictions. Though most of the people have surrendered their allegiance to their countries of origin, yet they sympathize, assist and express concern with people residing outside the confines of their political boundaries. Therefore, if properly harnessed, controlled and utilized; emerging social media platforms have the potentials to boost the security capacity of a state by engaging citizens' active participation in information gathering and sharing. People, who are in a dire humanitarian condition, can utilize varied social media platforms to draw the attention of the target audience and seek for assistance.

\section{Funding:}

It was a self-sponsored research.

\section{Ethical approval for the research:}

The study was conducted with ethical approval from the authority concerned.

\section{Conflict of Interest:}

There is no conflict of interest between the authors.

\section{Ethical Conduct of Research:}

We declare that this research has been conducted with accordance with extant ethical considerations for social research.

\section{References}

Adu-Atwere, J. (2015). The rise of BOKO haram and the missing girls. Unpublished Master's Thesis, Aalborg University.

Barna, J. (2014). Insecurity in context: The rise of Boko Haram in Nigeria: In-Depth Analysis. European Parliament. Directorate-General for External Policies, Policy Department, 2-23.

Bowd, R \& Chikwanha, A. B. (2010). Analysing causes of conflict, conflict resolution and peacemaking in Africa in understanding Africa's contemporary conflicts origins, challenges and peacebuilding. Monograph, 173, 1-306.

Bryman, A. (2008). Secondary analysis and official statistics. In: Bryman, Alan (ed.), Social Research Methods. Oxford University Press (3rd edition): 295-312

Cammaerts, B. (2015). Social media and activism, in Mansell, R., Hwa, P., The International Encyclopedia of Digital Communication and Society. Wiley-Blackwell, 1027-1034.

Castells, M. (2013). Networks of outrage and hope: Social movements in the Internet age. John Wiley \& Sons.

Dekker, P. and de Hart, J. (2005). Goede Burgers? In: Dekker, P \& de Hart, J (eds.). De Goede Burger. Tien beschouwingen over een morele categorie. Sociaal en Cultureel Planbureau, 11-19.

Development Initiatives (2017). Global Humanitarian Assistance Report 2017. Development Initiatives Ltd, 1-103.

DGIS (Directoraat-generaal Internationale Samenwerking) (2009). Investeren in mondiaalburgerschap. Tweede Kamer der Staten-Generaal, vergaderjaar 2008-2009, 31 250, nr. 58. Geraadpleegd van http:// ikregeer.nl/documenten/kst-31250-58.

Donnelly, E, Gwam, C U., Ariyo Obe, D. and Hillier, M. (2014). Nigeria's Boko Haram crisis: Abductions and responses. All-Party Parliamentary Group on Nigeria Meeting Summary, 1-7.

Elliott, A. (2009). Contemporary social theory: An introduction. Routledge Madison Avenue.

Hadji, A. (2016). Breaking boundaries: The opportunities for using social media in civil society networking, activism and civic engagement, in M. Kamp (Ed) Assessing the impact of social media on Political Communication and Civic Engagement in Uganda. Konrad-Adenauer-Stiftung.

Jonaski, T. and Gran, B. (2002). Political Citizenship: Foundations of rights, in E.F. \& Turner, B.S. (eds.). Handbook of Citizenship Studies. Sage Publications.

Lange-Ionatamishvili, E.and Svetoka, S. (2015). Strategic mmunications and social media in the Russia Ukraine conflict, in Kenneth Geers (Ed.), Cyberwar in perspective: Russian aggression against Ukraine. NATO CCD COE Publications,

Montagnese, A. (2012). Impact of social media on national security. Research Paper. Centro Militare di Studi strategici

Nissen, T. E. (2015). The weaponization of social media. characteristics of contemporary conflicts. Royal Danish Defence College.

Odeyemi, T.I \& Mosunmola, O.O. (2014). Stakeholders, ICTs platforms and the 2015 General Elections in Nigeria. Conference Paper Presented at the Department of Political Science, Obafemi Awolowo University Ile-Ife, Nigeria.

Omoera, O.S. and Ryanga, H. (2016). Can Social Media Set the Agenda in Addressing Violence Against Women? World Scientific News, 60, 40-50.

Onuoha, F.C. (2013). Report: porous borders and BOKO 
haram's arms smuggling operations in Nigeria. Al Jazeera Center for Studies.

Pandalai, S. (2016). The social media's challenge to national security: impact and opportunities a conceptual overview. IDSA Monograph Series, 55, $2-64$.

Patton, M., Foote, N., and Radner, J. (2015). A foundation's theory of philanthropy: What it is, what it provides, how to do it. The Foundation Review (7), 4. 1-15.

Pedde, N. (2011). La crisi libica, e le differenze con le rivolte in tunisia ed egitto, informazioni della difesa - smd, n. Research Paper 2011 STEPI - AE-U-3, 2-36.

Smith, C. (2015). The Technology of hope: Twitter and the \#BringBackOurGirls Campaign. Unpublished Master's Thesis, Royal Roads University Victoria, British Columbia, Canada.

Soi, C. (2017). A lawyer who helped Boko Haram schoolgirls' release wins UN award. http://www. aljazeera.com/news/2017/09/nigeria-teacherhelped-boko-haram-schoolgirls-release-wins award-170918092734050.html.

Ugorji, B. (2017). Bring Back Our Girls: A global movement for the release of the Chibok schoolgirls. International Center for Ethno-Religious Mediation (ICERM), 1-7.

University and College Union United Kingdom (UCU) (2015). One year on The abduction of the Chibok schoolgirls. Retrieved (19 th $^{\text {th }}$ January 2018) from https://www.ucu.org.uk/media/7211/One-year-on--Chibok schoolgirls/pdf/One_year_on_-_Chibok_ schoolgirls.pdf.

VOA News (2017). Nigerian Wins Prestigious Award for Aiding Victims of Boko Haram. Retrieved from (20 th January 2018), https://www.voanews.com/a/ nigerian-wins-prestigious-award-victims-of-Bokoharam/3994294.html.

Zeitzoff, T. (2017). How social media is changing conflict. Journal of Conflict Resolution, 1-12.

Muhammad Maigari Abdullahi a Ph.D. student at the Usmanu Danfodiyo University Sokoto. Currently, an Assistant Research Fellow, Department of Sociology, AL-Qalam University Katsina Nigeria.

Email: kariyoma2@yahoo.com

Uthman Abdullahi Abdul-Qadir is a Senior Lecturer at the Department of Sociology, Faculty of Social Sciences, Usmanu Danfodiyo University Sokoto-Nigeria. He holds Ph.D. in Sociology from the Bayero University Kano-Nigeria in 2016.

Email: Uthman50@yahoo.com 